\title{
Pushing the limits of neutron tomography in palaeontology: Three-dimensional modelling of in situ resin within fossil plants
}

\author{
Chris Mays, Joseph J. Bevitt, and Jeffrey D. Stilwell
}

\begin{abstract}
Computed tomography is an increasingly popular technique for the non-destructive study of fossils. Whilst the science of X-ray computed tomography (CT) has greatly matured since its first fossil applications in the early 1980s, the applications and limitations of neutron tomography (NT) remain relatively unexplored in palaeontology. These highest resolution neutron tomographic scans in palaeontology to date were conducted on a specimen of Austrosequoia novae-zeelandiae (Ettingshausen) Mays and Cantrill recovered from mid-Cretaceous (Cenomanian; 100-94 Ma) strata of the Chatham Islands, eastern Zealandia. Previously, the species has been identified with in situ fossil resin (amber); the new neutron tomographic analyses demonstrated an anomalously high neutron attenuation signal for fossil resin. The resulting data provided a strong contrast between, and distinct three-dimensional representations of the: 1) fossil resin; 2) coalified plant matter; and 3) sedimentary matrix. These data facilitated an anatomical model of endogenous resin bodies within the cone axis and bract-scale complexes. The types and distributions of resin bodies support a close alliance with Sequoia Endlicher (Cupressaceae), a group of conifers whose extant members are only found in the Northern Hemisphere. This study demonstrates the feasibility of NT as a means to differentiate chemically distinct organic compounds within fossils. Herein, we make specific recommendations regarding: 1) the suitability of fossil preservation styles for NT; 2) the conservation of organic specimens with hydrogenous consolidants and adhesives; and 3) the application of emerging methods (e.g., neutron phase contrast) for further improvements when imaging fine-detailed anatomical structures. These findings demonstrate that we are still far from reaching the conceptual limits of NT as a means of virtually extracting fossils, or imaging their internal anatomy even when embedded within a rock matrix.
\end{abstract}

Chris Mays. Department of Palaeobiology, Naturhistoriska riksmuseet, Box 50007, S-104 05 Stockholm, Sweden; School of Earth, Atmosphere and Environment, Monash University, 9 Rainforest Walk, Clayton, Victoria 3800, Australia. chris.mays@nrm.se

Joseph J. Bevitt. Australian Nuclear Science and Technology Organisation, Research Office, B3, New Illawarra Road, Lucas Heights, NSW 2234, Australia. jbv@ansto.gov.au

Mays, Chris, Bevitt, Joseph J., and Stilwell, Jeffrey D. 2017. Pushing the limits of neutron tomography in palaeontology: Threedimensional modelling of in situ resin within fossil plants. Palaeontologia Electronica 20.3.57A: 1-12. https://doi.org/10.26879/808 palaeo-electronica.org/content/2017/2066-neutron-scan-plant-resin 
Jeffrey D. Stilwell. School of Earth, Atmosphere and Environment, Monash University, 9 Rainforest Walk, Clayton, Victoria 3800, Australia and Australian Museum, 1 William Street, Sydney NSW 2010, Australia. jeffrey.stilwell@monash.edu

Keywords: Neutron tomography; resin; seed cone; Cupressaceae; Cretaceous; conservation

Submission: 25 July 2017 Acceptance: 13 November 2017

\section{INTRODUCTION}

When radio astronomy was first developed (Jansky, 1932), it provided a complementary means of examining the universe, and revealed objects and details beyond the domain of traditional optical telescopes. In an analogous sense, neutron tomography (NT) holds promise to reveal hitherto unknown details of even well-studied fossils, and solve palaeontological puzzles that have eluded more established methods, such as X-ray computed axial tomography (CT). Neutron tomography is an emerging technology in "virtual palaeontology" (sensu Sutton et al., 2014), and involves the differential transmission of neutron radiation through an object, and the construction of virtual, three-dimensional models from the residual radiation. The most commonly practiced technique in virtual palaeontology, CT, has become almost routine since its first fossil applications over 30 years ago (Tate and Cann, 1982; Conroy and Vannier, 1984). Whilst both CT and NT are non-destructive tomographic methods (cf. destructive tomography, e.g., thin sectioning; Sutton et al., 2014), NT holds greater promise to reveal hidden details when applied to fossils that are: 1 ) organically preserved (Sutton, 2008), due to the high attenuation of neutrons by hydrogenous substances (Vlassenbroeck et al., 2007); and 2) embedded within large volumes of rock matrix, because of the high penetration of neutrons through most sedimentary matrix types (e.g., Dawson et al., 2014). Recently, preliminary findings by Mays et al. (2017) suggested that NT may be capable of differentiating chemicallydistinct organic compounds within a given fossil; herein, we sought to test the applicability and limitations of NT for this purpose.

\section{GEOLOGICAL SETTING}

The Tupuangi Formation is the oldest sedimentary succession of the Chatham Islands, an archipelago in the southwestern Pacific Ocean (latitude: ca. $44^{\circ} \mathrm{S}$; longitude: ca. $\left.176^{\circ} \mathrm{W}\right)$. These intraplate volcanic islands are emergent portions of the primarily submerged subcontinent, Zealandia, which also incorporates New Zealand, New Caledonia, and Lord Howe and Campbell Islands (Figure 1.1). The Tupuangi Formation has been recorded only from Pitt Island (Māori: Rangiauria; Moriori: Rangiaotea), the second largest island of the archipelago (Figure 1.2). The unit comprises $>400 \mathrm{~m}$ of siliciclastic strata deposited in a fluviodeltaic system (Campbell et al., 1993; Mays and Stilwell, 2013) during tectonic extension prior to Cretaceous seafloor spreading between Zealandia and Antarctica (Laird and Bradshaw, 2004). The most complete outcrop succession of this unit occurs at Waihere Bay, on the northwestern portion of Pitt Island, and includes the fossil locality recorded herein (Figure 1.3). Based on spore-pollen biostratigraphy, the Tupuangi Formation has been constrained to the Cenomanian-Turonian stages of the lower Upper Cretaceous (ca. 100-90 Ma; Mildenhall, 1994; Mays and Stilwell, 2013).

The outcrop succession at Waihere Bay is dominated by interbedded carbonaceous siltstone and quartzofeldspathic fine to medium sandstone (Hay et al., 1970; Campbell et al., 1993; Mays and Stilwell, 2013, figure 4). Dozens of these siltstone horizons have yielded compression fossils of macroflora (Mays et al., 2015a, 2015b, 2017) and insects (Stilwell et al., 2016). The fossil plants of the Tupuangi flora tend to be organically preserved (coalified) compressions. Three-dimensional plant fossils recovered from the Tupuangi Formation, such as ovuliferous cones, are structurally supported by their enclosing siliciclastic sediments. Given the propensity of these fossils for severe in situ desiccation, manual extraction attempts have resulted in poor recovery of three-dimensional compressions fossils; however, non-destructive "virtual extraction" using neutron tomography has proven effective for their examination whilst still embedded in their sedimentary matrices (Mays et al., 2017). 


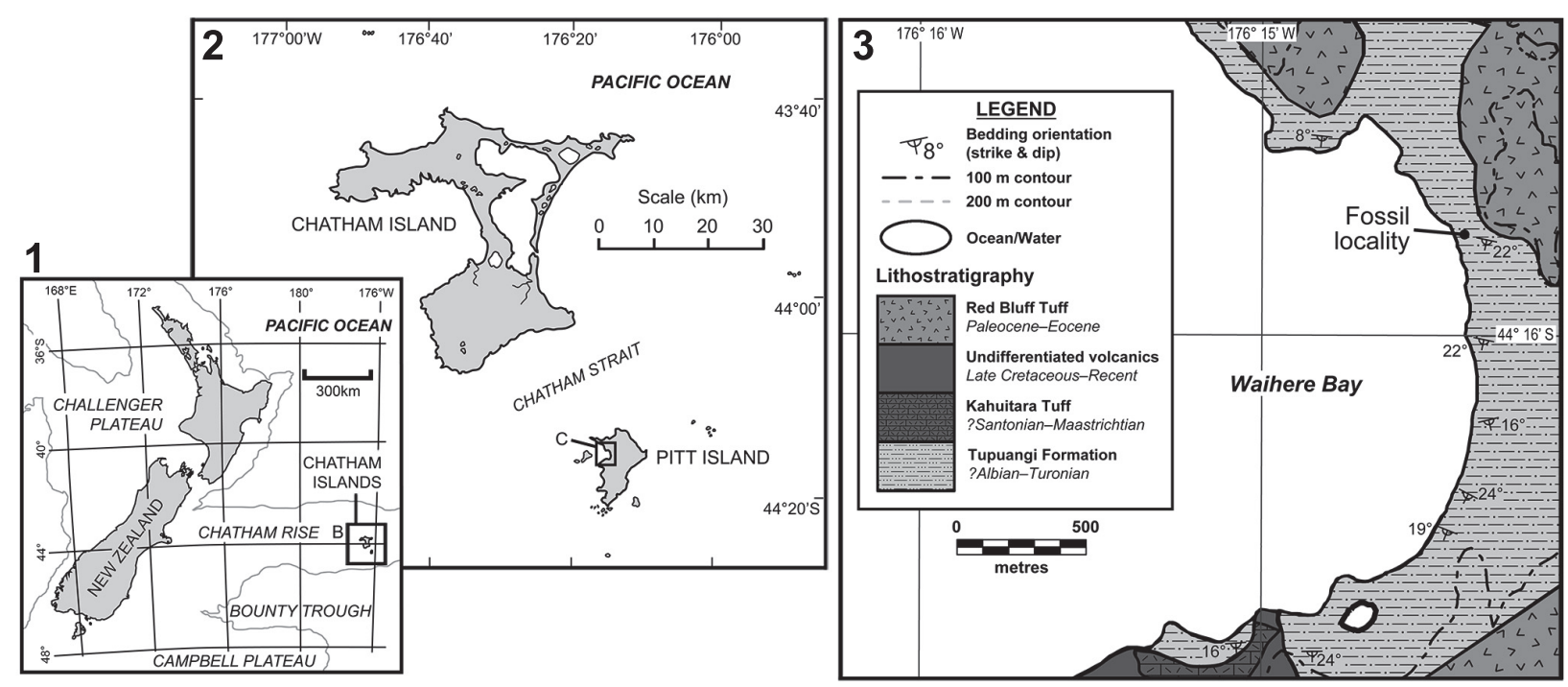

FIGURE 1. 1) Map of eastern Zealandia including New Zealand and the Chatham Islands, grey areas = emergent, grey outline $=2000 \mathrm{~m}$ isobath, boxed area is displayed in Figure 1.2. 2) Map of the Chatham Islands, grey areas = emergent, boxed area is displayed in Figure 1.3. 3) Geological map of the Waihere Bay area, northwest Pitt Island, fossil locality recorded in this study is indicated, age estimates from the following sources: Tupuangi Formation (Mildenhall, 1994; Mays and Stilwell, 2013), Kahuitara Tuff (Mildenhall, 1994; Stilwell, 1998), other estimates (Campbell et al., 1993; Panter et al., 2006). Modified from figures 1 and 3 of Mays et al. (2015b) with permission.

\section{MATERIALS AND METHODS}

\section{Sample and Locality Details}

Fossil material was collected from an outcrop of Tupuangi Formation at northern Waihere Bay, Pitt Island (Figure 1.3), by CM, JDS, M. Hall, and A. McMahon (Monash University) during the field season of January-February, 2009. The fossil locality corresponds to a stratigraphic height of 70 $\mathrm{m}$, as per the stratigraphic log presented by Mays and Stilwell (2013, figure 4). The fossil material has been deposited in the fossil collections at GNS Science, Lower Hutt, New Zealand, and designated a unique GNS sample registration code (prefix "PL") and field code (prefix "TPF"). The fossil was sourced from a horizon of light grey, carbonaceous siltstone, and co-occurred with Ginkgoites waarrensis Douglas, 1965 (Mays et al., 2015a). The fossil specimen had undergone coalification, with minimal carbonate or silicate permineralisation; this is a common form of preservation style for fossil plants (Scott, 2010) involving the retention of degraded organic compounds composed primarily of carbon, oxygen, and hydrogen (Hatcher and Clifford, 1997). The fossil bearing hand sample was trimmed with a dry slow saw to minimise the total hand sample volume, and matrix-to-fossil ratio prior to neutron tomographic scanning. The fossil locality is located at $44^{\circ} 15^{\prime} 49.6^{\prime \prime} \mathrm{S}, 176^{\circ} 14^{\prime}$ 22.6"W, and given the GNS Fossil Record File code $\mathrm{CH} / \mathrm{f0784}$. Photographs were taken with a Canon EOS 700D digital SLR camera fitted with an EF $50 \mathrm{~mm} / 2.5$ Macro lens; these are composed of multiple photographs taken at different focal depths, which were then digitally processed to increase the depth of field (à la Bercovici et al., 2009). This image stacking process was performed with the "Auto-Blend Layers" function of Adobe Photoshop CS6. Extant suprageneric taxa referred to herein follow the classification of Christenhusz et al. (2011).

\section{Neutron Tomography: Experimental Setup and Data Reconstruction}

Neutron tomography (NT) involves the transmission of neutrons through a target, and the conversion of the residual neutrons to photons. These photons were then collected as a series of photographs at discrete angles, and the resultant dataset was reconstructed into a virtual, threedimensional object for visualisation. The neutron source for this study was the Open-Pool Australian Lightwater (OPAL) reactor at the Australian Nuclear Science and Technology Organisation (ANSTO), Lucas Heights, New South Wales, Australia. These data were collected by JB, CM, M.-A. Harvey, and A. Langendam in January 2017 using the DINGO radiography/tomography/imaging station at ANSTO. Neutrons were converted to pho- 
tons with a $\mathrm{ZnS} / 6 \mathrm{LiF}$ scintillator screen $(50 \mu \mathrm{m}$ thick); photons were then detected by a liquid cooled, 16-bit Andor IKON-L CCD camera. Spatial resolution was increased by minimising the: 1) hand sample volume (as stated above); and 2) radiograph field of view. Primary scan parameters are outlined in Table 1; all additional NT experimental setup details not outlined herein follow Mays et al. (2017). Tomographic reconstruction was performed by JB, CM, M.-A. Harvey and A. Langendam using filtered backprojection with Octopus Reconstruction v.8.8 (Inside Matters NV). In order to reduce background radiation detection events, a cosmic ray filter was applied to all frames. Further reduction of background noise was achieved by the acquisition of three individual frames for each projection. During post-acquisition processing, the greyscale values of these frames were summed using the "Grouped ZProjector" plugin in ImageJ v.1.51h (National Institutes of Health); this plugin was developed by Holly (2004). Because of the substantial exposure length per frame (60 seconds), a minimal number of frames was an important consideration. Initial frame-summing tests revealed negligible additional noise reduction when projections were compiled from $>3$ frames. Scanning caused neutron activation in the sample, resulting in the emission of a hazardous amount of ionising radiation. The specimen was stored in a lead-lined container for four days, after which the newly radioactive isotopes had decayed to natural activity levels, safe enough for handling and long-term storage.

\section{Neutron Tomography: Visualisation and Segmentation}

From the neutron tomographic data, four distinct classes of components, or media, were digitally segmented from one fossil specimen and its associated sediment (PL1227). These media were: 1) air; 2) coalified plant remains; 3) fossil resin; and 4) sediment matrix. Volume rendering and segmentations were performed by $\mathrm{CM}$ using Avizo v.9.0.1 (FEl Company). The software produces a voxel frequency histogram of different greyscale values; these values reflect the relative neutron attenuation throughout the entire reconstructed sample volume (Figure 2.4). In this case, higher greyscale values on the distribution corresponded to higher neutron attenuation. To estimate the volumes of each medium, Avizo's "magic wand" tool was employed to automatically partition the four individual media based on their value ranges on the histogram. The boundaries on the histogram
TABLE 1. Neutron radiograph data collection parameters for illustrated specimen (PL1227).

\begin{tabular}{lc}
\hline \multicolumn{1}{c}{ Scan parameter } & Value \\
\hline Total sample dimensions $(\mathrm{mm})$ & $62 \times 58 \times 14$ \\
Scintillator composition & $\mathrm{ZnS} / 6 \mathrm{LiF}$ \\
Scintillator dimensions $(\mathrm{mm})$ & $100 \times 100 \times 0.05$ \\
Rotation angle $\left(^{\circ}\right)$ & 0.25 \\
Total rotation $\left(^{\circ}\right)$ & 180 \\
Projections & 720 \\
No. of frames/projection & 3 \\
Frame exposure (secs) & 60 \\
No. of dark and beam profile images & 6 each \\
Radiograph pixel width $(\mathrm{mm})$ & 0.0161 \\
\hline
\end{tabular}

(or "neutron attenuation segmentation thresholds") are demarcations points between any two media in the sample. These demarcation values were represented by local minima or inflection points between peaks or shoulders (Figure 2.4). The relative neutron attenuation ranges of these media were verified from surface expressions of each; absolute values could not be determined from by this approach due to slight beam hardening, which caused a greyscale heterogeneity across the reconstructed volume. Volume estimates of coalified plant material and resin were conducted on four completely preserved bract-scale complexes from this specimen. Resin volumes and segmentation thresholds are presented in Table 2.

\section{SYSTEMATIC TAXONOMY}

Subclass PINIDAE Cronquist, Takhtajan, and Zimmermann, 1966

Order CUPRESSALES Link, 1831

Family CUPRESSACEAE Gray, 1821

Subfamily SEQUOIOIDEAE (Luerssen, 1877)

Quinn in Gadek, Alpers, Heslewood, and Quinn, 2000

Genus AUSTROSEQUOIA Peters and Christophel, 1978

Type species. Austrosequoia wintonensis Peters and Christophel, 1978.

\section{Austrosequoia novae-zeelandiae (Ettingshausen, 1887) Mays and Cantrill \\ Figure 2, Appendix}

v. 2017 Austrosequoia novae-zeelandiae (Ettingshausen, 1887); Mays and Cantrill in Mays, Cantrill, Stilwell, and Bevitt, (in press), figs. 2, 3,6 . 

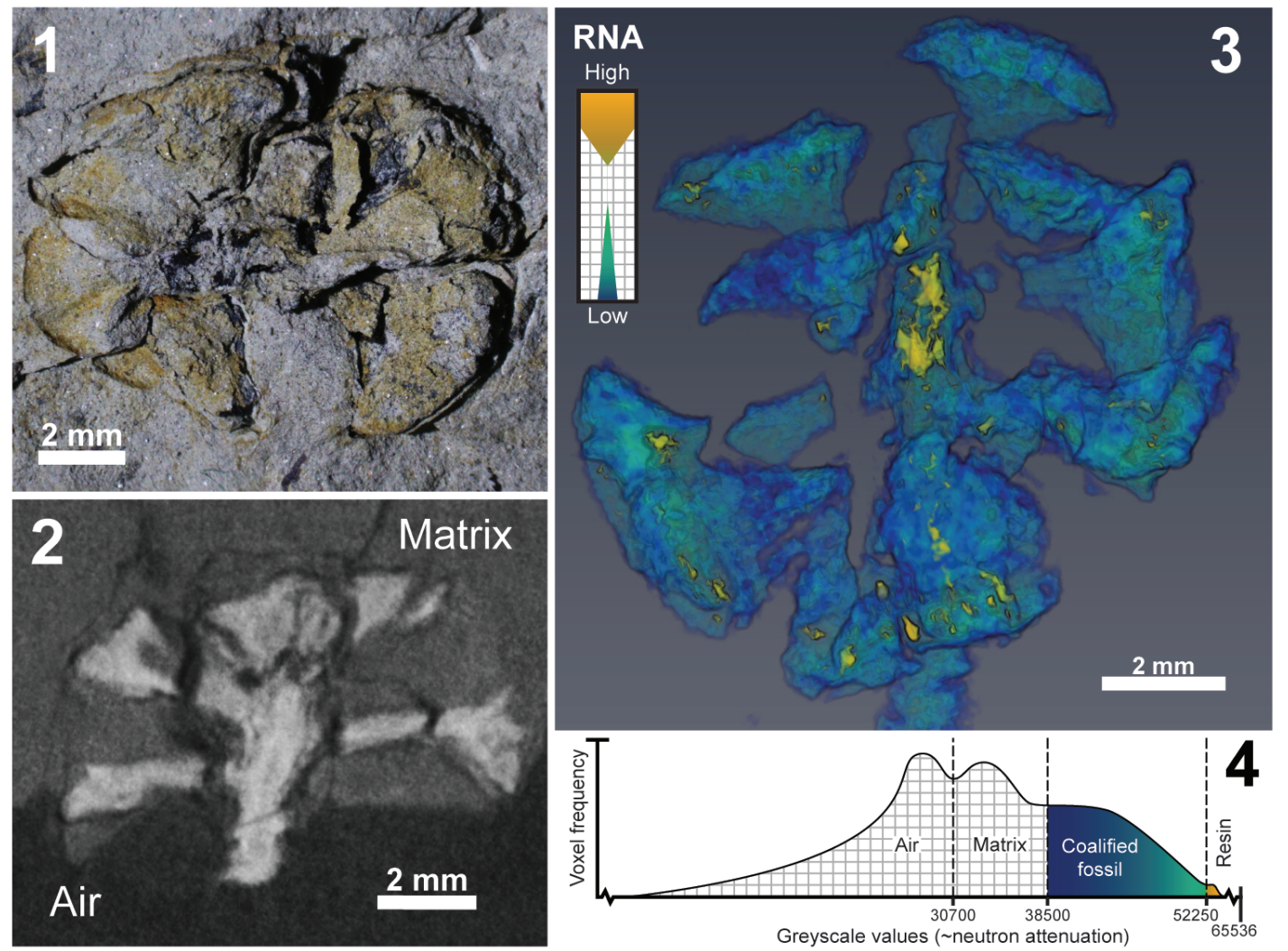

FIGURE 2. Austrosequoia novae-zeelandiae (Ettingshausen, 1887) Mays et al., 2017, PL1227. 1) Transverse section of a partially exposed, desiccated ovulate cone. 2) Neutron tomographic reconstruction largely encapsulated in sedimentary matrix, white indicates high neutron attenuation, oblique-transverse view. 3) Volume rendering of neutron tomographic reconstruction, RNA = Relative Neutron Attenuation, grid texture on RNA spectrum indicates relative transparency, regions of highest neutron attenuation represent in situ resin within cone axis and minor enclaves of resin near the distal ends of the bract-scale complexes, desiccation exhibited by large gaps in coalified organic remains (blue/green), oblique-transverse view. 4) Greyscale histogram from neutron tomographic reconstruction of PL1227 (16-bit) these values represent the neutron attenuation of the reconstructed volume, colours and transparency textures as per Figure 2.3, threshold values presented in Table 2, the spectrum has been cropped at the extremes for this graphical representation.

See Appendix for an animation of the virtually extracted specimen illustrated in Figure 2.3.

See Mays et al. (2017) for additional synonymy.

Description. Ovulate cone, woody, globose to ellipsoidal, $11.8 \mathrm{~mm}$ diameter, axial length not preserved, 11 preserved, helically arranged bractscale complexes. Cone axis slender $(1.4 \mathrm{~mm}$ in diameter), and enervated by at least two longitudinal resin canals. Bract-scale complexes are obtriangular in outline, peltate with pedicellate base, have a truncated apex and no apical protuberance. Complexes are $3.8-4.7 \mathrm{~mm}$ long, flaring at peltate distal head to $4.1-5.6 \mathrm{~mm}$ wide $\quad(\mathrm{N}=8)$. Ovuliferous scales and bracts are not clearly demarcated. Dorsal surface of complex has a longitudinal furrow/groove ( $<0.75 \mathrm{~mm}$ deep), bisected by a medial ridge, which is especially prominent on the lateral margins. Complexes have endogenous resin pockets; these tend to be elongated towards pedicellate base and subspherical towards distal margin. Minimum bract-scale complex resin volume was $0.9-1.6 \%$ (as a proportion of total cone bract-scale complex volume; see Present Limitations and Future Directions). There is no evidence of resin within associated fertile shoot; morphology of shoot not well-preserved enough to provide further details here.

Specimen examined. PL1227 (field code TPF0135-1).

Remarks. Axial length was not measurable, nor were all bract-scale complexes preserved, because of erosional truncation. All preserved characters of this specimen conform to previous specimens of Austrosequoia novae-zeelandiae from the Tupuangi Formation, Chatham Islands 
TABLE 2. Resin volume estimates and segmentation thresholds, all values are from visualisations performed with Avizo 9.0.1, volumes based on voxel diameter $=16.1 \mu \mathrm{m}$, "max." and "min." refer to the software maximum and minimum absolute spectrum values ( 0 and 65535 , respectively), total $=$ coalified plant remains + fossil resin, relative resin volume $(\%)=($ fossil resin $/$ total $) \times 100$.

\begin{tabular}{|c|c|c|c|c|}
\hline \multirow[b]{2}{*}{ Medium } & \multicolumn{2}{|c|}{$\begin{array}{c}\text { Neutron attenuation } \\
\text { segmentation thresholds }\end{array}$} & \multirow{2}{*}{$\begin{array}{c}\text { Volume } \\
\text { (no. of voxels) }\end{array}$} & \multirow{2}{*}{$\begin{array}{c}\text { Volume } \\
\left(\mu \mathrm{m}^{3}\right)\end{array}$} \\
\hline & Lower & Upper & & \\
\hline Air & Min. & 30700 & - & - \\
\hline Matrix & 30700 & 38500 & $1.60 \times 10$ & $6.67 \times 10^{12}$ \\
\hline \multicolumn{5}{|l|}{ Bract-scale complex 1} \\
\hline Coalified plant remains & 38500 & 52250 & $1.59 \times 10$ & $6.65 \times 10$ \\
\hline Fossil resin & 52250 & Max. & $2.61 \times 10$ & $1.09 \times 10$ \\
\hline Total & 38500 & Max. & $1.62 \times 10$ & $6.76 \times 10$ \\
\hline Relative resin volume (\%) & & & & 1.61 \\
\hline \multicolumn{5}{|l|}{ Bract-scale complex 2} \\
\hline Coalified plant remains & 38500 & 52250 & $7.05 \times 10$ & $2.94 \times 10$ \\
\hline Fossil resin & 52250 & Max. & $6.65 \times 10$ & $2.78 \times 10$ \\
\hline Total & 38500 & Max. & $7.12 \times 10$ & $2.97 \times 10$ \\
\hline Relative resin volume (\%) & & & & 0.94 \\
\hline \multicolumn{5}{|l|}{ Bract-scale complex 3} \\
\hline Coalified plant remains & 38500 & 52250 & $1.14 \times 10$ & $4.74 \times 10$ \\
\hline Fossil resin & 52250 & Max. & $9.98 \times 10$ & $4.16 \times 10$ \\
\hline Total & 38500 & Max. & $1.15 \times 10$ & $4.78 \times 10$ \\
\hline Relative resin volume (\%) & & & & 0.87 \\
\hline \multicolumn{5}{|l|}{ Bract-scale complex 4} \\
\hline Coalified cone scale & 38500 & 52250 & $8.49 \times 10$ & $3.54 \times 10$ \\
\hline Fossil resin & 52250 & Max. & $1.13 \times 10$ & $4.73 \times 10$ \\
\hline Total & 38500 & Max. & $8.60 \times 10$ & $3.59 \times 10$ \\
\hline Relative resin volume (\%) & & & & 1.32 \\
\hline
\end{tabular}

(Mays et al., 2017). However, the following additional characters were revealed by neutron tomography (Figure 2.3): 1) small endogenous resinous cells/pockets within the complexes; and 2) prominent resin reservoirs within the cone axis, delineating at least two resin canals (each up to $39 \%$ of the total axis diameter). These were revealed by the extraordinarily high neutron attenuation of fossil resin, relative to the surrounding coalified plant tissue (Table 2).

Stratigraphic range. The section of the stratigraphic succession from which the fossil was sourced has been correlated to the Ngaterian New Zealand chronostratigraphic stage (Mays and Stilwell, 2013), corresponding to the Cenomanian global stage (100.5-93.9 Ma; Raine et al., 2015). This species has previously been recorded from Cenomanian strata of the Chatham Islands (Mays et al., 2017), and ?Turonian-Campanian strata of mainland New Zealand (Pole, 1995).
Occurrences. Zealandia: 1) Waihere Bay, Chatham Islands (Mays et al., 2017); and 2) Shag Point, New Zealand (Ettingshausen, 1887).

\section{DISCUSSION}

\section{Neutron Tomography Improvements and Implications for Conservation and Phylogeny}

The present study follows-on from preliminary observations by Mays et al. (2017) of various organic compounds (e.g., fossil resin and coalified, woody plant tissue) can be differentiated with neutron tomography. In the previous publication, the presence of in situ resin for Austrosequoia novaezeelandiae was confirmed by visual association with numerous compression/impression fossils (e.g., figure 2). However, the poor resolution precluded the reliable description of endogenous resin. The improvements in study design herein permitted estimations of resin distributions and vol- 
umes, although these volumes must be considered minima (see Present Limitations and Future Directions). The relevant improved aspects were: 1 ) an increase in spatial resolution, whereby the radiograph pixel diameter for this specimen was $<50 \%$ than that achieved by Mays et al. $(2017 ; 16.1 \mu \mathrm{m}$ and $32.9 \mu \mathrm{m}$, respectively), the finest resolution of any palaeontological sample studied with neutron tomography to date; and 2) the frame-summing procedure, which facilitated an increase in signalto-noise ratio, and well-defined demarcations of different media. In regards to the latter measure, CT typically employs "frame-averaging" to reduce noise, whilst avoiding potential detector saturation (Sutton et al., 2014). In this NT experiment, framesumming was feasible because of the relatively low neutron flux, thus the chance of saturation from summing a small number of frames was negligible. Both of these techniques involve the capture of multiple frames, and the summing or averaging of these frames allows for the removal of anomalous noise. Such multiple-frame techniques are less common for NT, which typically involves much longer frame exposure times (60 sec herein), making the scanning process prohibitively long in many cases. The above combination of factors allowed the study of much finer anatomical structures (e.g., resin cysts) and gross morphological details (e.g., longitudinal ridges on the dorsal surfaces of the complexes), facilitating a full seed cone artist reconstruction of this species (Figure 3 ).

The delineation of different compositions revealed large desiccation fractures in this specimen (Figure 2.3, Appendix); from this, it was clear that the surrounding sedimentary matrix provides critical structural support. These cracks indicate a significant risk to the integrity of the specimen if subjected to manual extraction and associated removal of the matrix. Furthermore, Schulp et al. (2013) demonstrated the strong neutron attenuation response of common adhesives and consolidants applied to palaeontological samples. In the case of hydrogenous samples (like coalified plants), the attenuation contrast between these and the fossil target would likely be relatively low, thus obscuring their interfaces and may provide misleading morphological details. Furthermore, experimental scans conducted by the authors yielded poor results when scanning a hydrated sample, due to this lack of contrast (J.J. Bevitt and C. Mays; unpublished data). As such, if neutron tomography is under consideration, we recommend a minimalist approach to fossil preparation and conservation by avoiding these consolidation

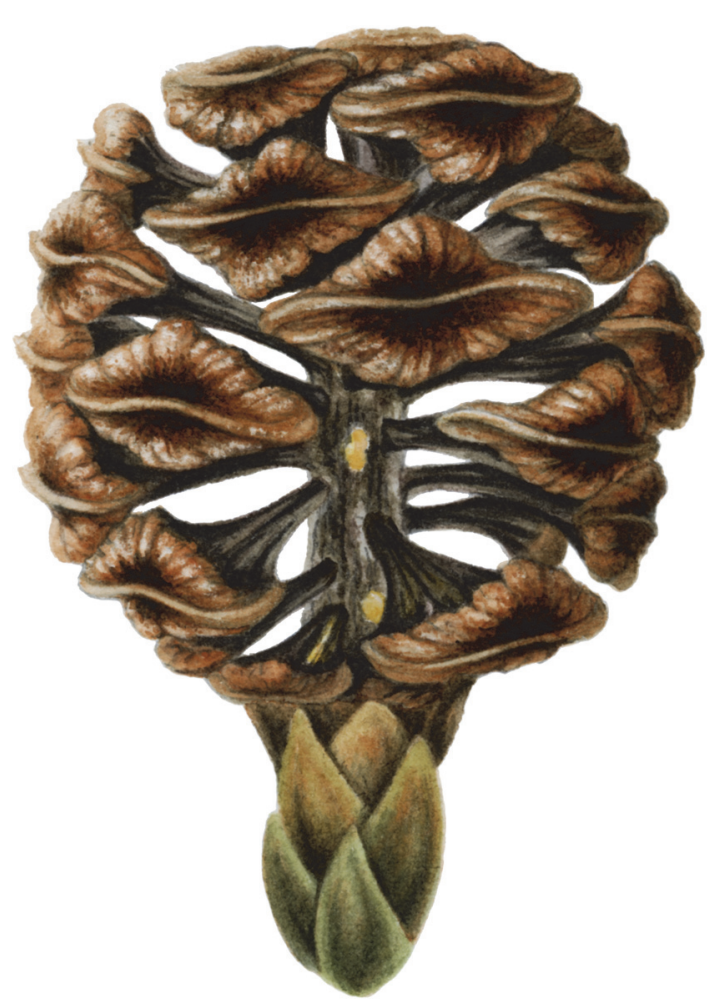

FIGURE 3. Artist's reconstruction of ovuliferous cone and fertile shoot of Austrosequoia novae-zeelandiae (Ettingshausen, 1887) Mays et al., 2017, artist: Mali Moir.

measures, and retain the fossil within the sedimentary matrix, even at the risk of in situ desiccation fractures. Because of the retention of hydrogenous components in coalified fossils, and the high attenuation of neutrons by hydrogen (Vlassenbroeck et al., 2007), neutron tomographic "virtual extraction" offers a uniquely-suited alternative to traditional extraction methods for this ubiquitous, but desiccation-prone plant fossil preservation style.

The types and distributions of these endogenous resin bodies support a close affinity of Austrosequoia novae-zeelandiae with Sequoia Endlicher, 1847 (Subfamily Sequoioideae), as originally suggested by Ettingshausen (1887). After a review of extant, resin-producing genera, Langenheim (2003) identified Sequoia as the only conifer genus, which exhibited both resin canals and resin pockets or cysts. Furthermore, it is likely that the resins of Austrosequoia are diterpenoid-based (Class I sensu Anderson et al., 1992), but follow-up chemical analyses are needed to confirm this.

\section{Present Limitations and Future Directions}

The stark contrast in neutron attenuation between fossil resin and the surrounding plant tis- 
sue or matrix allowed the detection of endogenous resin within the fossil plant. Fortunately, in situ resin is not uncommon for coalified plant remains, with numerous recently reported examples within Cupressaceae alone (e.g., Kvaček, 2002; Grimaldi and Nascimbene, 2010; Herrera et al., 2017; Sokolova et al., 2017). One important limitation to consider when applying NT to in situ resin distribution is: it is unlikely that, even when the plant was alive, all resin cavities (whether canals or cysts) would be entirely filled, so the resin distributions must be considered tentative, and volume estimates need to be taken as minima. The hazardous amount of ionising radiation emitted by the sample after neutron scanning reflects the radioactive decay of various isotopes which have undergone induced radioactivity ("neutron activation"). Minerals common in a siliciclastic sedimentary matrix prone to neutron activation would be primarily aluminosilicates (e.g., Na- and K-feldspars, and the mica group of phyllosilicates), because of the high activation potential of their constituent metals (specifically: Al, K, Na; IAEA, 2003). Depending on the abundance of such metals, the induced radioactivity of a specimen may preclude safe handling for up to several days; this may be an important factor when considering neutron tomography.

Neutron attenuation is largely a product of hydrogen density (Vlassenbroeck et al., 2007), making NT particularly relevant to hydrogenous, organically preserved fossils (e.g., coalified plants). When comparing the applicability of NT and CT on a palaeobotanical sample, Dawson et al. (2014) reported a greater attenuation contrast between organic (e.g., coalified plant) and inorganic (e.g., carbonate/silicate matrix) components for NT. The present study not only confirms a strong attenuation contrast between organics and inorganics, but also between two distinct organic compounds. Furthermore, Dawson et al. (2014) demonstrated a greater penetration for NT. This has since been supported by calculated penetration values through carbonate matrix for both X-rays and neutrons (De Beer, 2017). However, these experimental data have yet to be replicated, and it is likely that comparable X-ray penetration may be achieved at suitably high energies (R. Garwood, pers. comm.). Synchrotron CT has yielded excellent results with palaeobotanical samples, particularly those which have been preserved via silicification (e.g., Steart et al., 2014), or with pyrite/ calcium carbonate (e.g., Spencer et al., 2017). However, even if it can be demonstrated that CT can produce comparable or better sample penetra- tion, NT appears to provide superior attenuation contrast for organically preserved specimens within common, inorganic (carbonate or silicate) sedimentary matrices.

Whilst resin and coalified plant tissue were the only two components segmented from the fossil specimen, it is likely that NT will be applicable to a wider range of organic compounds if higher spatial resolutions can be achieved. Within organic materials, hydrogen density may be the result of chemical composition (e.g., terpenoid resin compounds vs. degraded lignin, as demonstrated in this study) and/or the physical structure of materials with comparable compositions (e.g., parenchyma vs. sclerenchyma; Grabber et al., 1991). An increase in spatial resolution should resolve such compositional and structural differences, even where they occur in close proximity. Fortunately, the present limits in NT resolution seem to be practical, rather than fundamental. Neutron radiographic experiments have achieved pixel widths of $<15 \mu \mathrm{m}$, although these have important practical issues precluding their routine use at present (including prohibitively long imaging durations and/or small fields of view; Williams et al., 2012; Faenov et al., 2015). Resolution limits can be further mitigated by neutron differential phase contrast techniques; these provide sharper boundaries between materials with subtle attenuation differences (Allman et al., 2000, Pfeiffer et al., 2006, Sutton et al., 2014), such as those you might expect between organic tissues within a single specimen. These advances demonstrate that conceptual hard limits in neutron radiography have not yet been reached. A combination of increased spatial resolution and phase contrast for NT holds great promise for component differentiation of both organic fossil and non-fossil samples.

\section{CONCLUSIONS}

Neutron tomographic scans of a coalified seed cone fossil (Austrosequoia novae-zeelandiae; Cupressaceae) revealed endogenous resin cysts and canals by the anomalously high neutron attenuation response of fossil resin. The anatomical features strengthen the phylogenetic placement of Austrosequoia as a Sequoioideae stem group, closely allied with Sequoia. These findings were enabled by acquiring the highest spatial resolution NT data of any palaeontological sample to date, and summing the data across multiple successive frames to minimise extraneous background signals. These findings support the unique suitability of NT for the three-dimensional gross morphology of organically preserved (hydrogenous) speci- 
mens, and can serve as an alternative to manual extraction, particularly when delicate and/or prone to desiccation. Furthermore, the results demonstrate the utility of NT for characterising some anatomical features in these specimens, even whilst still embedded within a sedimentary matrix. Despite the reported improvements, spatial resolution is still a key limitation of NT for many palaeontological applications, when compared to other digital tomographic techniques (e.g., micro-CT). Recommendations are made in regards to: 1) emerging techniques in NT to further mitigate these limitations (e.g., NT phase contrast); and 2) restricting the application of hydrogenous consolidants and adhesives on specimens that may be considered for NT. As advances in this technique continue, it is likely that increasingly subtle differences in hydrogen densities will be discernible, yielding a wider range of anatomical detail in organic fossil and sub-fossil specimens.

\section{ACKNOWLEDGEMENTS}

Special thanks go to palaeobotanical artist M. Moir and chief fossil preparator $\mathrm{C}$. Rodriguez. This work was made possible by technical advances on DINGO by U. Garbe (ANSTO). Thanks to M.-A. Harvey and A. Langendam for help with tomographic data collection, and to A. McMahon and M. Hall for their assistance in the field. The authors are indebted to the reviewers, R. Hill and R. Garwood, for their insightful suggestions; these vastly improved the quality of the manuscript. CM would like to thank the residents of Pitt Island for their field assistance and support, and to acknowledge the Moriori people as the original landowners of Rekohu (the Chatham Islands). This work was financially supported by the National Geographic Society [9761-15], the Australian Nuclear Science and Technology Organisation [P5521], and the Australian Research Council [DP140102515].

\section{REFERENCES}

Allman, B.E., McMahon, P.J., Nugent, K.A., Paganin, D., Jacobson, D.L., Arif, M., and Werner, S.A. 2000. Phase radiography with neutrons. Nature, 408:158-159. https://doi.org/10.1038/ 35041626

Anderson, K.B., Winans, R.E., and Botto, R.E. 1992. The nature and fate of natural resins in the geosphere II. Identification, classification and nomenclature of resinites. Organic Geochemistry, 18:829-841. https://doi.org/10.1016/0146-6380(92)90051-X

Bercovici, A., Hadley, A., and Villanueva-Amadoz, U. 2009. Improving depth of field resolution for palynological photomicrography. Palaeontologia Electronica, 12, 12.2.5T:12 pp., http:// palaeo-electronica.org/2009_2/170/index.html

Campbell, H.J., Andrews, P.B., Beu, A.G., Maxwell, P.A., Edwards, A.R., Laird, M.G., Hornibrook, N.D.B., Mildenhall, D.C., Watters, W.A., Buckeridge, J.S., Lee, D.E., Strong, C.P., Wilson, G.J., and Hayward, B.W. 1993. Cretaceous-Cenozoic Geology and Biostratigraphy of the Chatham Islands, New Zealand. Institute of Geological and Nuclear Sciences Limited, Lower Hutt, New Zealand.

Christenhusz, M.J.M., Reveal, J.L., Farjon, A., Gardner, M.F., Mill, R.R., and Chase, M.W. 2011. A new classification and linear sequence of extant gymnosperms. Phytotaxa, 19:55-70. https://doi.org/10.11646/phytotaxa.19.1.3

Conroy, G.C. and Vannier, M.W. 1984. Noninvasive three-dimensional computer imaging of matrix-filled fossil skulls by high-resolution computed tomography. Science, 226:456-458 https://doi.org/10.1126/science.226.4673.456

Cronquist, A., Takhtajan, A., and Zimmermann, W. 1966. On the higher taxa of Embryobionta. Taxon, 15:129-134. https://doi.org/10.2307/1217531

Dawson, M., Francis, J., and Carpenter, R. 2014. New views of plant fossils from Antarctica: A comparison of X-ray and neutron imaging techniques. Journal of Paleontology, 88:702-707. https://doi.org/10.1666/13-124

De Beer, F.C. 2017. Paleontology: fossilized awaken by neutron radiography, p. 141-171. In Kardjilov, N. and Festa, G. (eds.), Neutron Methods for Archaeology and Cultural Heritage. Springer International Publishing, Cham, Switzerland.

Douglas, J.G. 1965. The Mesozoic leaves Ginkgoites australis (McCoy) Florin, and Ginkgoites waarrensis n.sp. Mining and Geological Journal, 6:20-26.

Endlicher, S.F.L. 1847. Synopsis Coniferarum. Scheitlin und Zollikofer, St. Gallen.

Ettingshausen, C.F.v. 1887. Beiträge zur Kenntniss der fossilen flora Neuseelands. Denkschriften der Kaiserlichen Akademie der Wissenschaften, Wien, 53:143-194. 
Faenov, A., Matsubayashi, M., Pikuz, T., Fukuda, Y., Kando, M., Yasuda, R., likura, H., Nojima, T., Sakai, T., Shiozawa, M., Kodama, R., and Kato, Y. 2015. Using LiF crystals for highperformance neutron imaging with micron-scale resolution. High Power Laser Science and Engineering, 3, e27:9 pp. https://doi.org/10.1017/hpl.2015.28

Gadek, P.A., Alpers, D.L., Heslewood, M.M., and Quinn, C.J. 2000. Relationships within Cupressaceae sensu lato: a combined morphological and molecular approach. American Journal of Botany, 87:1044-1057. https://doi.org/10.2307/2657004

Grabber, J.H., Jung, G.A., and Hill, R.R. 1991. Chemical composition of parenchyma and sclerenchyma cell walls isolated from orchardgrass and switchgrass. Crop Science, 31:10581065. https://doi.org/10.2135/cropsci1991.0011183X003100040043x

Gray, S.F. 1821. The Natural Arrangement of British Plants. Volume 2. Baldwin, Cradock and Joy, London.

Grimaldi, D.A. and Nascimbene, P.C. 2010. Raritan (New Jersey) amber, p. 167-191. In Penney, D. (ed.), Biodiversity of Fossils in Amber from the Major World Deposits. Siri Scientific Press, Manchester, UK.

Hatcher, P.G. and Clifford, D.J. 1997. The organic geochemistry of coal: from plant materials to coal. Organic Geochemistry, 27:251-274. https://doi.org/10.1016/S0146-6380(97)00051-X

Hay, R.F., Mutch, A.R., and Watters, W.A. 1970. Geology of the Chatham Islands. New Zealand Geological Survey Bulletin, 83:1-86.

Herrera, F., Shi, G., Knopf, P., Leslie, A.B., Ichinnorov, N., Takahashi, M., Crane, P.R., and Herendeen, P.S. 2017. Cupressaceae conifers from the Early Cretaceous of Mongolia. International Journal of Plant Sciences, 178:19-41. https://doi.org/10.1086/689577

Holly, C. 2004. Grouped ZProjector (for ImageJ), https://imagej.nih.gov/ij/plugins/group.html. Holly Mountain Software, Waterville, Maine, USA. Accessed Jan 21, 2017.

IAEA 2003. Manual for Reactor Produced Radioisotopes. Industrial Applications and Chemistry Section, International Atomic Energy Agency, Vienna, Austria.

Jansky, K.G. 1932. Directional studies of atmospherics at high frequencies. Proceedings of the Institute of Radio Engineers, 20:1920-1932. https://doi.org/10.1109/JRPROC.1932.227477

Kvaček, Z. 2002. A new juniper from the Palaeogene of Central Europe. Feddes Repertorium, 113:492-502. https://doi.org/10.1002/fedr.200290001

Laird, M.G. and Bradshaw, J.D. 2004. The break-up of a long-term relationship: the Cretaceous separation of New Zealand from Gondwana. Gondwana Research, 7:273-286. https:// doi.org/10.1016/S1342-937X(05)70325-7

Langenheim, J.H. 2003. Plant Resins: Chemistry, Evolution, Ecology, and Ethnobotany. Timber Press, Inc., Portland, Oregon, USA.

Link, J.H.F. 1831. Handbuch zur Erkennung der nutzbarsten und am häufigsten vorkommenden Gewächse. Zweiter thiel. S.J. Joseephy, Berlin.

Luerssen, C. 1877. Grundzüge der Botanik. Von H. Haessel, Leipzig.

Mays, C., Cantrill, D.J., Stilwell, J.D., and Bevitt, J.J. (in press). Neutron tomography of Austrosequoia novae-zeelandiae comb. nov. (Late Cretaceous, Chatham Islands, New Zealand): Implications for Sequoioideae phylogeny and biogeography. Journal of Systematic Palaeontology. http://dx.doi.org/10.1080/14772019.2017.1314898.

Mays, C., Steinthorsdottir, M., and Stilwell, J.D. 2015a. Climatic implications of Ginkgoites waarrensis Douglas emend. from the south polar Tupuangi flora, Late Cretaceous (Cenomanian), Chatham Islands. Palaeogeography Palaeoclimatology Palaeoecology, 438:308-326. https://doi.org/10.1016/j.palaeo.2015.08.011

Mays, C. and Stilwell, J.D. 2013. Pollen and spore biostratigraphy of the mid-Cretaceous Tupuangi Formation, Chatham Islands, New Zealand. Review of Palaeobotany and Palynology, 192:79-102. https://doi.org/10.1016/j.revpalbo.2012.12.008

Mays, C., Tosolini, A.-M.P., Cantrill, D.J., and Stilwell, J.D. 2015b. Late Cretaceous (Cenomanian-Turonian) macroflora from the Chatham Islands, New Zealand: bryophytes, lycophytes and pteridophytes. Gondwana Research, 27:1042-1060. https://doi.org/10.1016/ j.gr.2014.03.017

Mildenhall, D.C. 1994. Palynological Reconnaissance of Early Cretaceous to Holocene Sediments, Chatham Islands, New Zealand. Institute of Geological and Nuclear Sciences Limited, Lower Hutt, New Zealand.

Panter, K.S., Blusztajn, J., Hart, S.R., Kyle, P.R., Esser, R., and Mclntosh, W.C. 2006. The origin of HIMU in the SW Pacific: evidence from intraplate volcanism in southern New Zealand and 
subantarctic islands. Journal of Petrology, 47:1673-1704. https://doi.org/10.1093/petrology/ egl024

Peters, M.D. and Christophel, D.C. 1978. Austrosequoia wintonensis, a new taxodiaceous cone from Queensland, Australia. Canadian Journal of Botany, 56:3119-3128. https://doi.org/ 10.1139/b78-374

Pfeiffer, F., Grünzweig, C., Bunk, O., Frei, G., Lehmann, E., and David, C. 2006. Neutron phase imaging and tomography. Physical Review Letters, 96:215505. https://doi.org/10.1103/ PhysRevLett.96.215505

Pole, M. 1995. Late Cretaceous macrofloras of eastern Otago, New Zealand: Gymnosperms. Australian Systematic Botany, 8:1067-1106. https://doi.org/10.1071/SB9951067

Schulp, A.S., Schouten, R., Metten, L., van de Sande, A., and Bontenbal, A. 2013. Tracking consolidant penetration into fossil bone using neutron radiography. Netherlands Journal of Geosciences, 92:177-180. https://doi.org/10.1017/S0016774600000123

Scott, A.C. 2010. Charcoal recognition, taphonomy and uses in palaeoenvironmental analysis. Palaeogeography, Palaeoclimatology, Palaeoecology, 291:11-39. https://doi.org/10.1016/ j.palaeo.2009.12.012

Sokolova, A., Gordenko, N., and Zavialova, N. 2017. The most ancient member of the Sequoioideae - the new genus Krassilovidendron Sokolova, Gordenko et Zavialova (Cupressaceae s.I.) from the Albian-Cenomanian of Western Siberia (Russia). Gondwana Research, 77:1-27. https://doi.org/10.1016/j.cretres.2017.04.014

Spencer, A.R.T., Garwood, R.J., Rees, A.R., Raine, R.J., Rothwell, G.W., Hollingworth, N.T.J., and Hilton, J. 2017. New insights into Mesozoic cycad evolution: an exploration of anatomically preserved Cycadaceae seeds from the Jurassic Oxford Clay biota. PeerJ, 5:e3723. https://doi.org/10.7717/peerj.3723

Steart, D.C., Spencer, A.R.T., Garwood, R.J., Hilton, J., Munt, M.C., Needham, J., and Kenrick, P. 2014. X-ray Synchrotron Microtomography of a silicified Jurassic Cheirolepidiaceae (Conifer) cone: histology and morphology of Pararaucaria collinsonae sp. nov. PeerJ, 2:e624. https://doi.org/10.7717/peerj.624

Stilwell, J.D. 1998. Late Cretaceous Mollusca from the Chatham Islands, New Zealand. Alcheringa, 22:29-85. http://dx.doi.org/10.1080/03115519808619238

Stilwell, J.D., Vitacca, J.J., and Mays, C. 2016. South polar greenhouse insects (Arthropoda: Insecta: Coleoptera) from the mid-Cretaceous Tupuangi Formation, Chatham Islands, eastern Zealandia. Alcheringa, 40:502-508. http://dx.doi.org/10.1080/ 03115518.2016 .1144385

Sutton, M.D. 2008. Tomographic techniques for the study of exceptionally preserved fossils. Proceedings of the Royal Society B, 275:1587-1593. https://doi.org/10.1098/rspb.2008.0263

Sutton, M.D., Rahman, I.A., and Garwood, R.J. 2014. Techniques for Virtual Palaeontology. Wiley Blackwell, Chichester, UK.

Tate, J.R. and Cann, C.E. 1982. High-resolution computed tomography for the comparative study of fossil and extant bone. American Journal of Physical Anthropology, 58:67-73. https:/ /doi.org/10.1002/ajpa.1330580108

Williams, S.H., Hilger, A., Kardjilov, N., Manke, I., Strobl, M., Douissard, P.A., Martin, T., Riesemeier, H., and Banhart, J. 2012. Detection system for microimaging with neutrons. Journal of Instrumentation, 7:P02014. https://doi.org/10.1088/1748-0221/7/02/P02014.

Vlassenbroeck, J., Cnudde, V., and Masschaele, B. 2007. A comparative and critical study of Xray $C T$ and neutron $C T$ as non-destructive material evaluation techniques, p. 277-285. In Přikryl, R. and Smith, B.J. (eds.), Building Stone Decay: From Diagnosis to Conservation. The Geological Society of London, London, UK. https://doi.org/10.1144/

GSL.SP.2007.271.01.26 
MAYS, BEVITT, \& STILWELL: NEUTRON SCAN PLANT RESIN

\section{APPENDIX.}

Austrosequoia novae-zeelandiae (Ettingshausen, 1887) Mays et al., 2017, animated volume rendering of neutron tomographic reconstruction, Relative Neutron Attenuation (RNA) spectrum and scale as per Figure 2, PL1227. For animation see palaeo-electronica.org/content/2017/ 2066-neutron-scan-plant-resin.

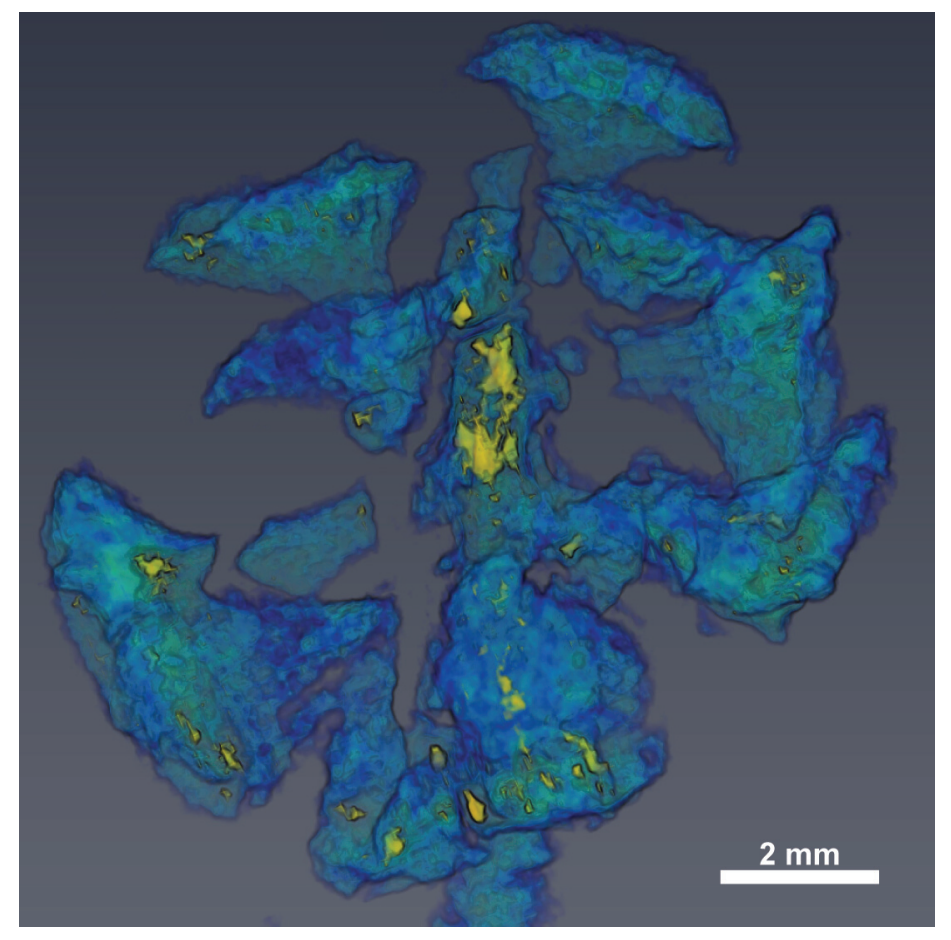

